\title{
PERAN SERTA MASYARAKAT DALAM PERLINDUNGAN DAN PENGELOLAAN LINGKUNGAN HIDUP
}

\begin{abstract}
Yasminingrum $^{*}$
ABSTRACT

Protection and environmental management to ensure the fulfillment and protection of the environment as a part of human rights. As part of the human rights protection and management of the environment in the use of natural resources implemented harmonious, harmonious and balanced with environmental functions. The use of natural resources is based on government policies that are imbued with the obligation to conserve the environment and realize the goal of sustainable environmental development. One way to realize the goal of environmentally sustainable development is to optimize the participation of the community in the protection and management of the environment.
\end{abstract}

Keywords: Society, protection, management, environment.

\section{PENDAHULUAN}

Krisis lingkungan hidup merupakan tantangan yang sangat besar pada abad ini.Tantangan ini didapati terutama di negara-negara yang sedang membangun, karena adanya berbagai aktivitas pem bangunan yang bertujuan meningkatkan kesejahteraan umat manusia yang sering pula membawa dampak terhadap perubah an lingkungan.

Aktivitas pembangunan yang tidak disertai dengan pengawasan dan pengelola an lingkungan hidup yang baik mengakibat kan malapetaka pada umat manusia. Dengan demikian konsep pengawasan, pengelolaan dan pelaksanaan undangundang lingkungan hidup merupakan kunci utama terhadap pencapaian kelestarian lingkungan.

Perkembangan ilmu pengetahuan, teknologi dan industri yang cepat pada saat ini tentu sangat dirasakan pengaruhnya, baik dampak positif maupun dampak negative dan dampak negative ini harus

* Yasminingrum, Dosen Fakutas Hukum Universitas 17 Agustus 1945 Semarang dapat dihubugi melalui email : rudi241260 @gmail diwaspadai agar tidak menjadi malapetaka bagi kehidupan masa kini maupun masa yang akan dating. Masalah-masalah lingkungan hidup dapat menjadi bencana yang dapat mempengaruhi kualitas kehidupan manusia. Tanda-tanda masalah lingkungan hidup seperti : ${ }^{1}$ adanya polusi, pemanasan global, fotokimia kabut, hujan asam,erosi, banjir, intrusi/pengikisan dan sebagainya, telah mulai kelihatan sejak pertengahan abad ke 20. Pada era globalisasi ini, liputan media massa dapat memberikan informasi yang sangat cepat tentang kejadian-kejadian kerusakan lingkungan yang disebabkan oleh pengelolaan lingkungan yang kurang tepat.

Akibat pengelolaan yang tidak benar dan akibat pencemaran lingkungan, diperkirakan dalam masa 300 tahun belakangan ini telah banyak species yang sudah punah dari bumi, dan semakin lama akan semakin bertambah, sehingga suatu saat manusia juga akan dapat menjadi korban kepunahan. ${ }^{2}$ Dalam proses

1 Walhi, Laporan Kegiatan Walhi Tahun 19952000, 2001

2 Usman R, Pokok Pokok Hukum Alam Sekitar Nasional, Akademika Pressindo, Jakarta, 1993, hal 16 
pembangunan, kehadiran undang-undang dan peraturan tentang lingkungan hidup erat kaitannya dengan kualitas fisik dan nilai ekologi suatu kawasan. ${ }^{3}$

Sumber daya alam yang kita miliki merupakan karunia dari Tuhan Yang Maha Esa, maka sebagai bangsa Indonesia wajib mengelola, memanfaatkan dan memelihara sumber daya alam untuk memajukan kesejahteraan umum sebagaimana diamanatkan oleh Undang Undang Dasar 1945 dan untuk mencapai kebahagiaan hidup berdasarkan Pancasila. Untuk itu guna menunjang kesejahteraan perlu melaksanakan pembangunan yang berwawasan lingkungan yang berdasarkan kepada kebijaksanaan nasional yang terpadu dan menyeluruh dengan memperhitungkan kebutuhan generasi kini dan masa depan. Hal ini supaya pengelolaan lingkungan hidup tetap menjadi sumber dan penunjang bagi rakyat dan bangsa Indonesia serta mahkluk hidup lainnya demi kelangsungan hidup dan peningkatan kualitas hidup itu sendiri.

Perlindungan dan Pengelolaan lingkungan hidup merupakan tanggung jawab kita bersama, pemerintah harus selalu menumbuhkembangkan kesadaran masyarakat akan pentingnya lingkungan hidup yang baik. Disamping itu dalam pengelolaan dan pelestarian lingkungan hidup peran serta masyarakat, baik perorangan maupun lembaga swadaya masyarakat juga harus ikur berperan serta.Dengan demikian harus ada kerjasama antara pihak pemerintah, pihak industri dan masyarakat.

Oleh karena itu dalam rangka mewujudkan cita-cita pembangunan yang berwawasan lingkungan, peran serta masyarakat menjadi sesuatu yang penting.Untuk itu akan dikaji secara ilmiah tentang peran serta masyarakat dalam

3 Djanius Djamin, Pengawasan Dan Pelaksanaan Undang Undang Lingkungan Hidup, Suatu Analisis Sosial, Yayasan Obor Indonesia, Jakarta, 2007, hal 15 perlindungan dan pengelolaan lingkungan hidup.

\section{PEMBAHASAN}

Undang Undang Dasar Negara Republik Indonesia Tahun 1945 di dalam pasal 33 ayat (3) memberi petunjuk bahwa bumi, air, dan kekayaan alam yang terkandung didalamnya adalah pokokpokok kemakmuran rakyat, sehingga harus dikuasai negara untuk digunakan sebesarbesarnya kemakmuran rakyatkemakmuran rakyat sebesar-besarnya merupakan arah pembangunan jangka panjang yang tertuju pada pembangunan manusia Indonesia seutuhnya dan pembangunan seluruh masyarakat Indonesia. Hal ini berarti bahwa pembangunan tidak hanya mengejar kemajuan lahiriah ataupun batiniah, melainkan keselarasan, keserasian dan keseimbangan antara lahiriah dan batiniah.

Bangsa Indonesia menghendaki keselarasan hubungan antara manusia dengan Tuhannya, antara sesama manusia, antara manusia dengan lingkungan alam sekitarnya, keserasian hubungan antara bangsa dan keselarasan antara cita-cita hidup di dunia dan mengejar kebahagiaan di akhirat.

Untuk meningkatkan kemakmuran rakyat perlu dilaksanakan pembangunan secara berencana karena kegiatan-kegiatan pembangunan merupakan aktivitas yang merubah lingkungan yaitu dapat mempengaruhi struktur dasar ekosistem yang berupa terganggunya keseimbangan antara komponen-komponen ekosistem dan berupa pencemaran yang menimbulkan kerusakan bagi berfungsinya proses-proses alam dalam ekosistem.Kerusakan tersebut dapat menimbulkan gangguan terhadap kelangsungan hidup manusia.

Resiko yang ditimbulkan oleh pembangunan dapat berupa :

1. Rusaknya berbagai sistem pendukung perikehidupan yang vital bagi manusia, baik sistem biofisik maupun sosial; 
2. Munculnya bahaya-bahaya baru akibat ciptaan manusia, seperti bahan berbahaya dan beracun dan hasil-hasil bioteknologi;

3. Pengalihan beban resiko kepada generasi berikutnya atau kepada daerah lain, dan;

4. Kurang berfungsinya sistem organisasi sosial dalam masyarakat. ${ }^{4}$

Menyadari akan hal tersebut, maka pemerintah mengusahakan untuk dapat mengurangi dan menghindarkan resiko yang diakibatkan oleh pembangunan dengan Undang Undang No. 23 Tahun 1997 Tentang Pengelolaan Lingkungan Hidup.

Secara formal kita telah mempunyai undang -undang yang mengatur lingkungan hidup adalah tahun 1982 yaitu Undang Undang No. 4 Tahun 1982Tentang PokokPokok Pengelolaan Lingkungan Hidup. Undang Undang tersebut menjadi landasan untuk menilai dan menyesuaikan semua peraturan perundang-undangan yang memuat ketentuan tentang segi-segi lingkungan hidup yang kini berlaku. Dalam hubungannya dengan ini, maka Undang Undang Lingkungan Hidup tersebut disusun untuk dapat berfungsi sebagai : "ketentuan payung (umbrella provision) bagi penyusunan peraturan perundangundangan tentang lingkungan lainnya",5

${ }^{5}$ Kemudian Undang Undang No. 4 Tahun 1982 digantikan dengan Undang Undang No. 23 Tahun 1997, dan terakhir dengan Undang No. 32 Tahun 2009 Tentang Perlindungan dan Pengelolaan Lingkungan Hidup.

Pengaturan hukum lingkungan mulai mendapat perhatian dunia sejak diselenggarakan konperensi PBB tentang Lingkungan Hidup Manusia di Stockholm Tahun 1972 yang berhasil merumuskan danmensahkan The United Nations Conference On The Human Environment,

4 Harun M Husein, Lingkungan Hidup Masalah Pengelolaan Dan Penegakkan Hukumnya, Sinar Grafika, Jakarta, hal 108.

5 St Munadjat Danusaputro, Hukum Lingkungan Buku I: Umum, Bina Cipta, Jakarta, 1985, hal 25. dan Action Plan For The Human Environment.

Deklarasi PBB disamping menghasilkan deklarasi tentang lingkungan hidup juga membentuk badan PBB yang disebut United Nations Environment Programme (UNEP). Kemajuan lebih lanjut yaitu dengan dibentuknya komisi dunia untuk lingkungan dan pemerintah (WCED), dengan tugas :

1. Mengajukan strategi jangka panjang pengembangan lingkungan menuju pembangunan yang berkelanjutan di tahun 2000 dan sesudahnya;

2. Mengajukan cara-cara supaya keprihatinan lingkungan dapat dituang kan dalam kerja sama antra negara untuk mencapai keserasian antara kependudukan, sumber daya lam, lingkungan dan pembangunan;

3. Mengajukan cara-cara supaya masyarakat internasional dapat menanggapi secara lebih efektif pola pembangunan berwawasan lingkung an; dan

4. Mengajukan cara-cara masalah lingkungan jangka panjang yang dapat ditanggapi dalam agenda aksi untuk dasawarsa pembanungan. ${ }^{6}$

Dengan terbitnya tahun 1972, nampak sangat nyata gerak peningkatan usaha pembangunan hukum lingkungan di masyarakat internasional. Yang penting dalam menanggapi proses pembentukan hukum baru adalah meneliti dan mengkaji konvensi-konvensi internasional dan regional, baik yang sudah ada maupun yang kini sedang berkembang, agar tidak terjadi rumusan hukum yang berbeda antara negara yang satu dengan negara yang lain dan rumusan antara hukum lama dengan hukum yang sekarang.

Dalam hubungannya dengan ini, maka bilamana kita menghargai lingkungan hidup terhadap manusia ada ancaman, bahaya dan pemburukannya yang

6 RM Gatot Sumartono, Mengenal Hukum Lingkungan, Sinar Grafika, jakarta, 1991, hal 2425 
akan mengakibatkan kerusakan ekologis, maka patut dipertanyakan : Apakah hukum kita harus kaku dan tatalaksananya tidak luwes yang mengakibatkan kita tidak mampu berbuat sesuatu pada saat metode dan konsep lama tidak lagi memadai dan tidak mampu menangani kasus-kasus lingkungan baru. $^{7}$

Banyak pendapat pakar di bidang lingkungan hidup dalam memberikan pendifinisian "lingkungan hidup". Dalam hal ini akan diambil rumusan dari ST Munadjat Danusaputro, yaitu mengatakan bahwa lingkungan hidup diartikan sebagai semua benda dan kondisi termasuk di dalamnya manusia dan tingkah perbuatan nya, yang terdapat dalam ruang tempat manusia berada dan mempengaruhi hidup dan kesejahteraan manusia dan jasad hidup lainnya. $^{8}$

Pengertian lingkungan hidup secara yuridis digariskan dalam pasal 1 angka 1 Undang Undang No. 32 Tahun 2009 yang berbunyi "lingkungan hidup adalah kesatuan ruang dengan semua benda, daya, keadaan, dan makhluk hidup, termasuk manusia dan perilakunya, yang mem pengaruhi alam itu sendiri, kelangsungan perikehidupan dan kesejahteraan manusia serta makhluk hidup lainnya"

Dari pengertian tersebut, lingkung an hidup manusia itu dapat digolongkan atas :

1. Lingkungan fisik, adalah segala sesuatu di sekitar kita yang berbentuk benda mati seperti rumah, kendaraan, gunung, udara, sinar matahari dan lain yang semacamnya.

2. Lingkungan biologis, adalah segala sesuatu yang berada disekitar manusia yang berupa organisme hidup lainnya selain dari manusia sendiri, binatang, tumbuh-tumbuhan, jasad renik (plankton) dan lain-lain.

7 M Daud Silalahi, AMDAL Dalam Sistem Hukum Lingkungan Indonesia, Mandar Maju, Bogor, hal 7

8 Op Cit, hal 45
3. Lingkungan sosial, adalah manusia lain yang berada disekitarnya seperti tetangga, teman dan lain-lain.'

Pembangunan yang kita lakukan seringkali dapat menimbulkan suatu malapetaka, hal ini karena dengan melaksanakan pembangunan berarti melakukan aktivitas yang merubah lingkungan.Perubahan yang dihasilkan oleh pembangunan sebagian telah direncenakan dan sebagian lagi di luar perencenaan.Perubahan yang tidak terencana kita sebut dengan efek sampingan atau dampak.

Dampak lingkungan akan mempengaruhi kehidupan manusia, sosial budaya, sosial ekonomi, flora dan fauna. Hal tersebut mengakibatkan:

1. Gangguan kesehatan pada manusia/ masyarakat;

2. Terjadinya perubahan manusia dan masyarakat yang diakibatkan oleh aktivitas pembangunan;

3. Banyak tumbuhan dan hewan yang mati.

Dampak lingkungan hidup menurut pasal 1 angka 26 UU No. 32 Tahun 2009 Tentang Perlindungan dan Pengelolaan Lingkungan Hidup, adalah pengaruh perubahan pada lingkungan hidup yang diakibatkan oleh suatu usaha dan/atau kegiatan. Dalam kaitannya dengan dampak lingkungan perlu diperhatikan mengenai daya dukung lingkungan. Yang dimaksud dengan daya dukung lingkungan hidup menurut pasal 1 angka 7 UU No. 32 Tahun 2009 tersebut adalah kemampuan lingkungan hidup untuk mendukung perikehidupan manusia dan makhluk hidup lain dan keseimbangan antara keduanya.

Bahaya yang senantiasa meng ancam kelestarian lingkungan adalah pencemaran dan perusakan lingkungan. Masalah pencemaran timbul bilamana suatu zat atau energi dengan tingkat

9 Fuad Amsyari, Prinsip-prinsip Masalah Pencemaran Lingkungan, Ghalia Indonesia, Jakarta, hal 11-12 
konsentrasi yang sedemikian rupa hingga dapat mengubah kondisi lingkungan, baik langsung atau tidak langsung, dan pada akhirnya lingkungan tidak berfungsi sebagaimana mestinya. Pencemaran lingkungan menimbulkan kerugian dalam bentuk:

1. Kerugian ekonomi dan sosial (economic \& social injury) dan;

2. Gangguan sanitary (sanitary hazard). ${ }^{10}$

Pencemaran lingkungan hidup sebagaimana tertulis dalam pasal 1 angka 14 UU No. 32 Tahun 2009 Tentang Perlindungan Dan Pengelolaan Lingkung an Hidup adalah masuk atau dimasukkan nya makhluk hidup, zat, energi, dan/atau komponen lain ke dalam lingkungan hidup oleh kegiatan manusia sehingga melampui baku mutu lingkungan hidup yang telah ditetapkan.

Sedangkan perusakan lingkungan hidup sebagaimana dalam pasal 1 angka 16 UU No. 32 Tahun 2009 Tentang Perlindungan dan Pengelolaan Lingkungan Hidup, adalah tindakan orang yang menimbulkan perubahan langsung atau tidak langsung terhadap sifat fisik dan/atau hayati lingkungan hidup sehingga melampui criteria baku kerusakan lingkungan hidup.

Dalam ketentuan pasal 1 angka 2 UU No. 32 Tahun 2009 Tentang Perlindungan Dan Pengelolaan Lingkung an Hidup dikatakan bahwa perlindungan dan pengelolaan lingkungan hidup adalah upaya sistematis dan terpadu yang dilakukan untuk melestarikan fungsi lingkungan hidup dan mencegah terjadinya pencemaran dan /atau kerusakan lingkungan hidup yang meliputi yang meliputi perencanaa, pemanfaatan, pengendalian, pemeliharaan, pengawasan, dan penegakan hukum.

Peran serta masayarakat dalam perlindungan dan pengelolaan lingkungan hidup mempunyai jangkauan luas, tidak

10 RM Sutamihardja, Kualitas Dan Pencemaran Lingkungan, IPB, Bogor, 1978, hal 3 hanya meliputi peran para individu yang terkena berbagai peraturan atau keputusan administrative, akan tetapi meliputi pula peran kelompok dan organisasi dalam masyarakat. Pola pikir yang melandasi perlunya peran masyarakat adalah :

1. Memberi informasi kepada pemerintah, peran serta masyarakat sangat diperlukan untuk memberi masukan kepada pemerintah tentang masalah yang dapat ditimbulkan oleh sesuatu rencana tindakan pemerintah dengan berbagai konsekuensinya. Dengan demikian pemerintah akan dapat mengetahui adanya berbagai kepentingan yang dapat terkena tindakan tersebut yang perlu diperhatikan.

2. Meningkatkan kesediaan masyarakat untuk menerima keputusan, seorang warga masyarakat yang telah memperoleh kesempatan untuk berperan serta dalam proses pengambilan keputusan dan tidak dihadapkan pada suatu fait accompli, akan cenderung untuk memperlihatkan kesediaan yang lebih besar guna menerima dan menyesuaikan diri dengan keputusan tersebut.

3. Membantu perlindungan hukum, apabila sebuah keputusan akhir diambil dengan memperhatikan keberatan-kebertan yang diajukan oleh masyarakat selama proses pengambil an keputusan berlangsung, maka dalam banyak hal tidak aka nada keperluan untuk mengajukan perkarea ke pengadilan.

Mendemokratisasikan pengambil keputusan, karena di dalamnya terdapat akses atau partisipasi rakyat dan pelaksanaan program merupakan realisasi dari bentuk kepedulian masyarakat dalam penegakan hukum lingkungan. ${ }^{11}$

11 Koesnadi Hardjosoemantri, Aspek Hukum Peran Serta Masyarakat Dalam Pengelolaan Lingkungan Hidup, Gama University Press, Jogjakarta, 1986, hal 3-4 
Peran masyarakat memerlukan penyaluran informasi kepada masyarakat dengan cara yang berhasilguna dan berdayaguna. Dalam hubungan ini, berbagai masalah perlu mendapatkan perhatian diantaranya :

1. Pemastian penerima informasi

Peraturan perundang-undangan di berbagai negara memuat ketentuan yang mengharuskan badan-badan yang ber sangkutan untuk mengumumkan rencana kegiatan dalam penerbitan resmi dan atau melalui media massa, baik pada tingkat local, propinsi maupun tingkat nasional tergantung pada ruang lingkungan rencana tersebut. Badan-badan tersebut diwajibkan pula untuk memamerkan dalam kurun waktu tertentu dokumen-dokumen seperti misalnya uraian proyek, permohonan ijin dan sampai batas tertentu juga laporan hasil studi serta berbagai pendapat dan saran.Pameran dokumen-dokumen tersebut dilakukan ditempat umum yang mudah dikunjungai masyarakat.

\section{Informasi lintas batas}

Masalah yang sangat penting adalah yang ditimbulkan oleh pencemaran lintas batas (transfrontier pollution). Bentuk dan kegiatan pencemaran tetentu di daerah perbatasan dapat melintasi batas negara dan memberikan dampak kepada warga masyarakat yang hidup di negara yang berbatasan.

3. Informasi yang tepat waktu.

Peran masyarakat yang berhasil guna memerlukan informasi sedini dan seteliti mungkin. Informasi perlu diberikan pada saat belum diambil sesuatu keputusan yang mengikat serta masih ada kesempatan untuk mengusulkan alternative-alternatif lain.

4. Informasi lengkap

Informasi yang disampaikan selengkap mungkin dan data yang dikemukakan bersifat akurat sehingga memudahkan untuk dipahami masyarakat luas dalam segala lapisan.

5. Informasi yang dapat dipahami
Suatu informasi harus dipahami oleh warga masyarakat, karena kalau tidak maka informasi tersebut tidak berguna sama sekali. ${ }^{12}$

Guna mendayagunakan dan menghasilgunakan peran masyarakat dalam perlindungan dan pengelolaan lingkungan hidup perlu dipenuhi persyaratan:

1. Pemimpin eksekutif yang terbuka;

2. Peraturan yang akomodatif;

3. Masyarakat yang sadar lingkungan;

4. Lembaga swadaya masyarakat yang tanggap

5. Informasi yang tepat;

6. Keterpaduan. ${ }^{13}$

UU No. 32 Tahun 2009 Tentang Perlindungan Dan Pengelolaan Lingkungan Hidup mengatur mengenai hak dan kewajiban serta peran masyarakat dalam pengelolaan lingkungan hidup.Kemandirian dan keberdayaan masyarakat merupakan prasyarat untuk menumbuhkan kemampuan masyarakat sebagai pelaku dalam pengelolaan lingkungan hidup bersama dengan pemerintah dan pelaku pembangunan lainnya.Hal ini telah diatur dalam Pasal 70 UU No. 32 Tahun 2009, di mana masyarakat memiliki hak dan kesempatan yang sama dan seluas-luasnya untuk berperan aktif, sehingga peran masyarakat dapat berupa pengawasan social, pemberian saran, pendapat, usul, keberatan, pengaduan, dan/atau penyampaian informasi dan/atau laporan.

Meningkatnya kemampuan dan kepeloporan masyarakat akan meningkatkan efektivitas peran masyarakat dalam pengelolaan lingkungan hidup. Meningkatknya ketanggapsegeraan masyarakat akan semakin menurunkan kemungkinan terjadinya dampak negative. Dengan meningkatnya ketanggapsegeraan

12 Ibid, hal 5-6

13 Ibid, hal 16 
akan meningkatkan kecepatan pemberian informasi tentang masalah lingkungan hidup sehingga dapat segera ditindak lanjuti.

\section{KESIMPULAN}

Peran serta masyarakat dalam perlindungan dan pengelolaan lingkungan hidup didayagunakan sebagai alat untuk mendapatkan masukan berupa informasi dalam pengambilan keputusan. Pengambilan keputusan yang mendapat dukungan masyarakat pada tiap tingkatan pengambilan keputusan didokumentasikan dengan baik akan menjadikan keputusan yang kredibilitas.

\section{DAFTAR PUSTAKA}

Djanius Djamin, 2007 Pengawasan Dan Pelaksanaan Undang Undang Lingkungan, Suatu Analisis Sosial, Yayasan Obor, Jakarta, 2007

Fuad Amsari, 1006 Prinsip Prinsip Masalah Pencemaran Lingkungan, Ghalia Indonesia, Jakarta
Husein M Harun,2009 Lingkungan Hidup Masalah Pengelolaan Dan Penegakan Hukumnya, Sinar Grafika, Jakarta

Koenadi Hardjosoemantri, 1986 Aspek Hukum Peran Serta Masyarakat dalam Pengelolaan Lingkungan Hidup,Gama University Prss, Jogjakarta,

M Daud Silalahi,2010 Amdal, Dalam system Hukum Lingkungan Indonesia, Mandar Maju, Bogor.

RM Sutamihardja, 1978. Kualitas Dan Pencemaran Lingkungan, IPB, Bogor,

RM Gatot Sumartono, 1991 Mengenal Hukum Lingkungan, Sinar Grafika, Jakarta,

ST Munadjat Danusaputro, 1985 Hukum Lingkungan Buku I : Umum, Bina Cipta,

Jakarta, Usman R, 1993 Pokok Pokok Hukum Alam Sekitar Nasional, Akademika Pressindo, Jakarta,

Walhi, Laporan Kegiatan Tahaun 19952000, 2001 